\title{
Atmospheric significance of aeolian salts in the sandy deserts of northwestern China
}

\author{
B.-Q. Zhu \\ Key Laboratory of Water Cycle and Related Land Surface Processes, Institute of Geographic Sciences and Natural Resources \\ Research, Chinese Academy of Sciences, Beijing 100101, China \\ Correspondence to: B.-Q. Zhu (zhubingqi@igsnrr.ac.cn)
}

Received: 7 November 2015 - Published in Solid Earth Discuss.: 3 December 2015

Revised: 18 January 2016 - Accepted: 18 January 2016 - Published: 4 February 2016

\begin{abstract}
Large sandy deserts in the middle latitudes of northwestern China were investigated for soluble salt variations in modern and ancient aeolian sediments, aiming to explore the environmental significance of "aeolian salts". Results revealed that aeolian salt variations have a clear relationship with the changing meridional and zonal gradients of the desert locations and the aeolian differentiation effect, but are weakly linked to local geological conditions. Atmospheric depositions of water-soluble chemical species are an important process/source contributing to aeolian salt. Sequential variations of soluble salts in sedimentary profiles interbedded with aeolian and non-aeolian deposits and their palaeoenvironmental implications in the hinterland areas of these deserts were further evaluated, based on the constraints of OSL dating and radiocarbon dating data. The results indicate that inorganic salts may be a latent geoproxy in revealing regional palaeoclimatic changes in desert areas for sediments deposited under a single depositional environment, but the interpretation should be more cautious for sediments deposited under diverse depositional conditions. This study presents evidence of the atmospheric origin of aeolian salt in sandy deserts, with limited climatic significance in palaeoenvironmental reconstruction.
\end{abstract}

\section{Introduction}

Salt deposits (evaporites) are found in locations as diverse as Antarctica to the equatorial latitudes, and in depositional settings ranging from intracontinental to marginal marine (Handford, 1991). Much of what we know about ancient sedimentary facies and their depositional environments has been derived from the study of modern sedimentary environments. The formation of soluble/inorganic salts in many types of deposits (e.g. soils, playa, and lake sediments) is supposed to be governed mainly by climate factors including annual precipitation inputs, soil moisture changes, evapotranspiration losses, and solar radiation (Borchert and Muir, 1964; Sinha and Raymahashay, 2004; Warren, 2006; Singer, 2007). Thus salt archives in sediments are critical to understanding a number of geochemical processes in the supergene environment of the hydrogeologic and hydroclimatic systems. For instance, the soluble salt mineral assemblages embody significant signals indicating the processes of the solutes origin and transportation after their deposition (Warren, 2006; Zhu and Yang, 2010). Because soluble salts in soil/sediments response sensitively to regional-scale climate and hydrology changes (Borchert and Muir, 1964; Smoot and Lowenstein, 1991), they have been used as a key environmental proxy indicator in sedimentary records of oceans, lakes, sandy deserts, and loess-palaeosol sediments (Borchert and Muir, 1964; Sinha and Raymahashay, 2004; Hay et al., 2006; Warren, 2006; Sun et al., 2006; Liu et al., 2008; Sun et al., 2008). In these case studies, vertical variations of salt solutes in sediment strata are used as a geoproxy to indicate past salinity conditions and climatic changes in many parts of the world (Wasson et al., 1984; Last, 1990; Dean and Schwalb, 2000; Schutt, 2000; Last and Vance, 2002; Sinha and Raymahashay, 2004).

In arid conditions the desert landscape is globally distributed. For these areas, non-marine salt deposits are common features of modern arid closed basins. Research on salt deposits under arid climate has been documented over a long time; however, the environmental implications of inorganic 
salt formation in desert areas are still not clear, to a certain extent because of the diverse compositions of salt solutes with complicated formation mechanisms in different geomorphologic units. Research on salt formation has been performed worldwide in different arid conditions, with the main purpose to identify the relationship between salt regime and environmental factors - for instance, salt formation in different clay types (Rengasamy et al., 1984), hydrological distribution (Borchert and Muir, 1964; Warren, 2006), fire ashes (Lasanta and Cerda, 2005; Bodi et al., 2012, 2014), soil erosion (Lasanta and Cerda, 2005; Cerda et al., 2013; Agata et al., 2015), hydrological distribution (Borchert and Muir, 1964; Warren, 2006; Bodi et al., 2012), geomorphologic setting and dust source (Wang et al., 2008), volcanism and atmospheric fixation (Oyarzun and Oyarzun, 2007), rainfall patterns (Ahuja, 1990; Dragovich and Dominis, 2008), and mean annual climatic conditions (Dan and Yaalon, 1982; Lavee et al., 1991; Pariente, 2001), but relatively few such relationships have been recognized in the aeolian sediments. Until now, few investigations have dealt with the environmental implications of salt deposits from the sandy deserts in northern China (Zhu and Yang, 2010; Zhu et al., 2012), although these deserts comprise the majority of middle-latitude deserts in the temperate zone of the Northern Hemisphere $(\mathrm{NH})$.

In this work we present a physical and geochemical exploration into inorganic solutes filtrated from aeolian sediments collected from the inland sandy deserts in northwestern China, representing a cross-section of different environments (from westerly to monsoon climate control) in the $\mathrm{NH}$ middle latitudes. The objective of the paper is to explore the atmospheric significance of inorganic salts in aeolian sediments and their possible climatic implications.

\section{Methodology}

The study areas and sampling sites were chosen from wellknown sandy deserts in China (Fig. 1a), i.e. the Taklamakan Desert in the Tarim Basin (the westerly climate control) and the Badain Jaran Desert in the Alex Plateau (the monsoon climate control). Both the modern and ancient aeolian sediments were targeted to be sampled in the field. For modern aeolian sediment, 33 dunes in the Taklamakan Desert and 14 dunes in the Badain Jaran Desert were sampled in the field. The modern sands were sampled from the active dune surface. The geographical locations of these sample sites are mainly in dune fields from the centre and southern edges of the Taklamakan Desert (Fig. 1b) and the southern inland area in the Badain Jaran Desert (Fig. 1c-d).

In the inner part of the Taklamakan and the Badain Jaran deserts, aeolian and lacustrine (or fluvial in Taklamakan) deposits (palaeosediments) are frequently found interbedded (Fig. 2). For instance, lacustrine/fluvial sediment strata widely occur in the hinterland dune fields of the Taklamakan
Desert along the N-S oil-transporting highway (Fig. 2a-b). Four sedimentary sequences with clear stratigraphical layers were selected from hinterland areas of the two deserts in this study (Fig. 1). There is about $4 \mathrm{~m}$ of depth for the ArerjilinI section from the Badain Jaran Desert (Fig. 1d). Lacustrine sediments in this section were interbedded by aeolian sand layers (Fig. 3a). The Tazhong-XIII section in the Taklamakan Desert (Fig. 3b) is in general a lacustrine sequence interlayered with dune sediments. The Yaogan-VIII section is situated at the lower reaches of the Keriya River (Fig. 1b) close to the south margin of the Taklamakan Desert. The top of this section is buried by a $30 \mathrm{~m}$ active dune (Fig. 3c). The Tumiya-II section is located at the low reaches of the Tumiya palaeochannel close to the south edge of the Taklamakan Desert (Fig. 1b). This section is in general a silty sand or sandy silt sequence interlayered by cemented calcium carbonate layers (Fig. 3d). In general, the lithologies of the lacustrine sediments are very different from those of the aeolian sediments in all sedimentary sequences from the Taklamakan Desert. These sequences were chronologically analysed based on optically stimulated luminescence (OSL) dating and radiocarbon $\left({ }^{14} \mathrm{C}\right)$ dating methods.

Details of the analytical methods for soluble salt geochemistry of the aeolian sediment samples can be found in Zhu and Yang (2010), and the OSL and radiocarbon dating methods are from Yang et al. $(2006,2010)$. The physical and chemical analytical data of the soluble salt compositions of sediments are shown in Supplement Tables S1 and S2, respectively. The resulting OSL and radiocarbon dating ages are summarized in Supplement Tables S3 and S4, respectively. Note that the partial characteristics of aeolian salts from the Taklamakan and Badain Jaran deserts were previously reported in our early works (Zhu and Yang, 2010; Zhu et al., 2012) with preliminary descriptions of their composition and distribution and related influencing factors, but their complete stratigraphies and chronological results are presented here along with other new palaeoenvironmental estimations.

\section{Results}

Salinity values for all samples are mathematically calculated based on TDS values of the filtrates and their water-sediment mass ratios. The $\mathrm{pH}$ and the calculated salinity values for the dune sediments from the Taklamakan Desert range between 8.66 and 9.54 (mean 9.22) and 0.27 and $1.86 \%$ (mean $0.78 \%$ ), respectively. For the dune sediments in the Badain Jaran Desert, the $\mathrm{pH}$ and the salinity values lie between 8.82 and 9.42 (mean 9.12) and 0.05 and $0.42 \%$ (mean $0.15 \%$ ), respectively. The range of $\mathrm{pH}$ values between the aeolian sediments is narrow (8.6-9.5). This indicates that the soil conditions and acid buffer capacities for these deserts are similar, generally of alkaline nature. Studies have shown that $\mathrm{pH}$ values in soil between 6.4-12.2 are mainly caused by bicarbonate (6.4-10.3) and carbonate (10.3-12.2) (Wetzel and Likens, 

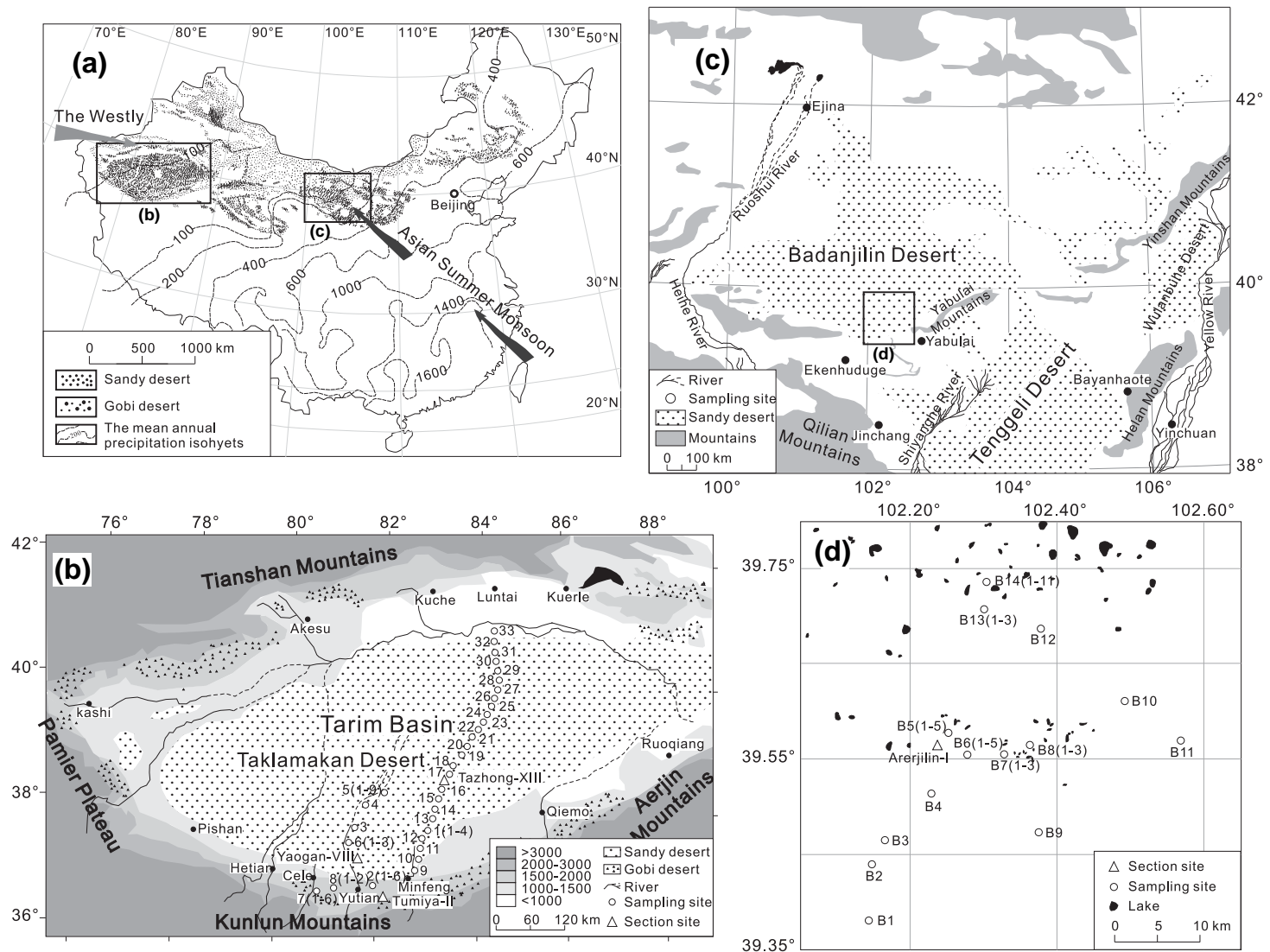

Figure 1. Locations of the study areas and sampling sites in this study. (a) The distributions of deserts and the mean annual precipitation isohyets in China, (b) the Taklamakan Desert, (c) and (d) the Badain Jaran Desert.

2000). This thus means that the alkalinities of aeolian salts in Chinese deserts are mainly controlled by the carbon-bearing salts, particularly bicarbonate.

For the 15 palaeo-aeolian sediment samples buried beneath modern dunes in the Taklamakan Desert with OSL ages ranging between 40-2 ka BP (Supplement Table S4), the salinities and $\mathrm{pH}$ values are slightly higher in salinity and lower in $\mathrm{pH}$ than those of modern dune sand samples (Fig. 4a). The modern dune samples collected from the identical months in different climatic year (such as the autumns in the arid 2006 and in the wet 2008) in the Badain Jaran Desert are quite similar to each other (Fig. 4b).

The major anions of aeolian salts are $\mathrm{Cl}^{-}$and $\mathrm{HCO}_{3}^{-}$ in all samples. The $\mathrm{SO}_{4}^{2-}$ concentrations are relatively low (Fig. $4 \mathrm{~d}$ ). $\mathrm{Na}^{+}$is the first major cation and $\mathrm{Ca}^{2+}$ is the second. The concentrations of $\mathrm{K}^{+}$and $\mathrm{Mg}^{2+}$ are relatively low (Fig. 4e-f). It should be noted that the carbon-bearing ion concentrations in these sediments are highly correlated with $\mathrm{pH}$ (Fig. 4c). Based on charge balances and mass matches between major cations and anions, the potential salt mineralogy of these aeolian sediments can be categorized as: $\mathrm{NaHCO}_{3}$ $+\mathrm{NaCl}+\left(\mathrm{CaCO}_{3}\right)$ in the Badain Jaran Desert (Fig. 4g), and $\mathrm{NaCl}+\mathrm{NaHCO}_{3}$ in the Taklamakan Desert (Fig. 4h).
This indicates that the assemblage of sodium carbonate and chloride is widely distributed in aeolian sediments within the Chinese sandy deserts.

The fingerprint diagrams of the ion distribution patterns for aeolian sediment solutes, local groundwaters, and surface waters are shown in Fig. 5a-b. The distribution patterns for dune surface sediments from the Badain Jaran Desert are different from the local groundwaters and the local lake waters (Fig. 5a). The chemical differences between aeolian salts and natural waters are also evident in the Taklamakan Desert (Fig. 5b), particularly in the patterns of magnesium and sulfate. These factors reflect a weaker influence of local waters on aeolian salts both in the Badain Jaran and Taklamakan deserts.

For the Taklamakan Desert, the salt salinities of aeolian sediments have a strongly positive correlation with the median grain sizes of the corresponding samples (Mz in phi unit, Fig. 5c), indicating an enrichment of soluble salts towards the finer particles of aeolian sediments. The same trend is observed in the Badain Jaran Desert, with the salt concentrations in different grain size fractions increasing as particle fractions become finer (Fig. 5d). 


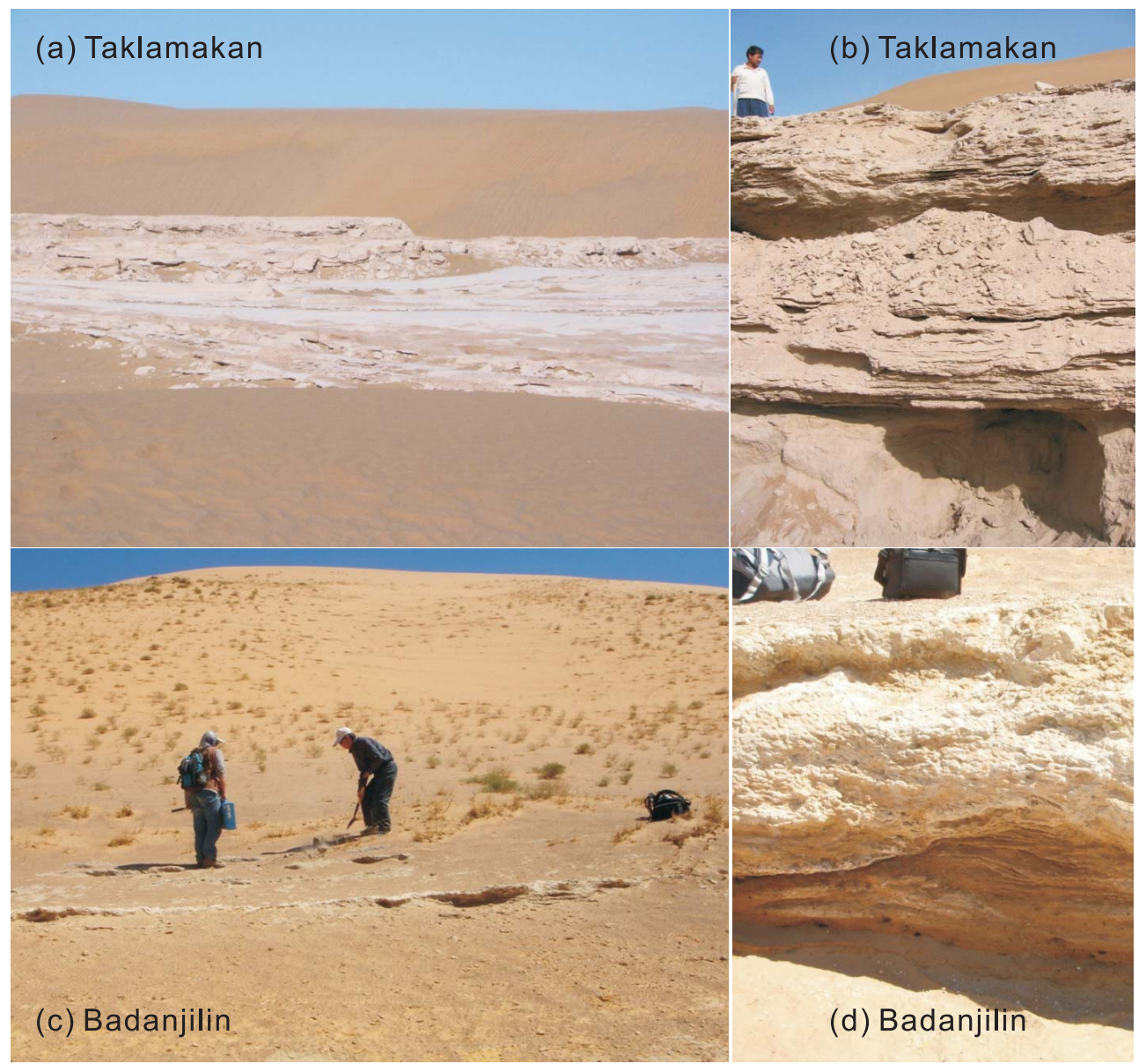

Figure 2. Photograph views of Quaternary and modern sediments of aeolian and lacustrine/fluvial facies that consisted of clay and sand/silt sand alternations in the Taklamakan and Badain Jaran deserts. (a) and (b) the Taklamakan Desert, (c) and (d) the Badain Jaran Desert.

In dune surface sediments from the two deserts along the longitude (E) and latitude (N) lines of sampling sites, the salt salinities show regularly varied trends, with an increasing salinity together with decreases of the longitude and latitude degrees, respectively (Fig. 5e-h). Because mean annual precipitation in northern China increases gradually along the same meridional direction, and the temperature or mean solar radiation decreases along the same latitudinal gradients, this indicates that enrichment of aeolian salt content has a clear relationship with the changing meridional and zonal gradients of the sample locations, which correspond to the regional climatic gradient, as well as the aeolian effects of granularity differentiation caused by wind/atmospheric dynamics, but there is a weak link with local hydrological conditions.

For the Arerjilin-I section in the Badain Jaran Desert, black carbon from the highest shorelines of Arerjilin Lake $(+10 \mathrm{~m})$ were dated to $5628 \pm 221 \mathrm{calyr}$ BP (CNR-185, Fig. 3a and Supplement Table S3). Calcareous gyttja (+6 m) and black carbon $(+5.5 \mathrm{~m})$ from deposits above the lake surface were dated to $4757 \pm 315 \mathrm{cal}$ yr BP (CNR-173) and
$7144 \pm 200$ cal yr BP (CNR-186), respectively (Fig. 3a and Table S3). Normally, deposits are younger at locations below the highest lake level. However, in this case it is believed that younger sediments were removed by wind erosion. Consequently, the older lacustrine sediments are now exposed at the surface.

The Tazhong-XIII section contains three lacustrine layers interbedded by aeolian sand sediments (Fig. 3b). The OSL age of the bottom aeolian layer is $39800 \pm 2900$ a (Supplement Table S4). Aeolian layers underlying the top two lacustrine layers are dated to $28000 \pm 2300 \mathrm{a}$ and $29200 \pm 2600 \mathrm{a}$. The age limits of the lower lacustrine layer range between ca. 40000 and 30000 a ago (Fig. 3b).

Lacustrine strata in the Yaogan-VIII section are intercalated with two aeolian sand layers (Fig. 3c). The aeolian sands underlying the lacustrine section is dated to $14500 \pm 1100$ a (Table S4), and the aeolian sands overlying the lacustrine section is dated to $2320 \pm 180 \mathrm{a}$. The age constraints of aeolian sand layers indicate that the palaeolake was dried between ca. 14000 and 2000 a (Fig. 3c). 

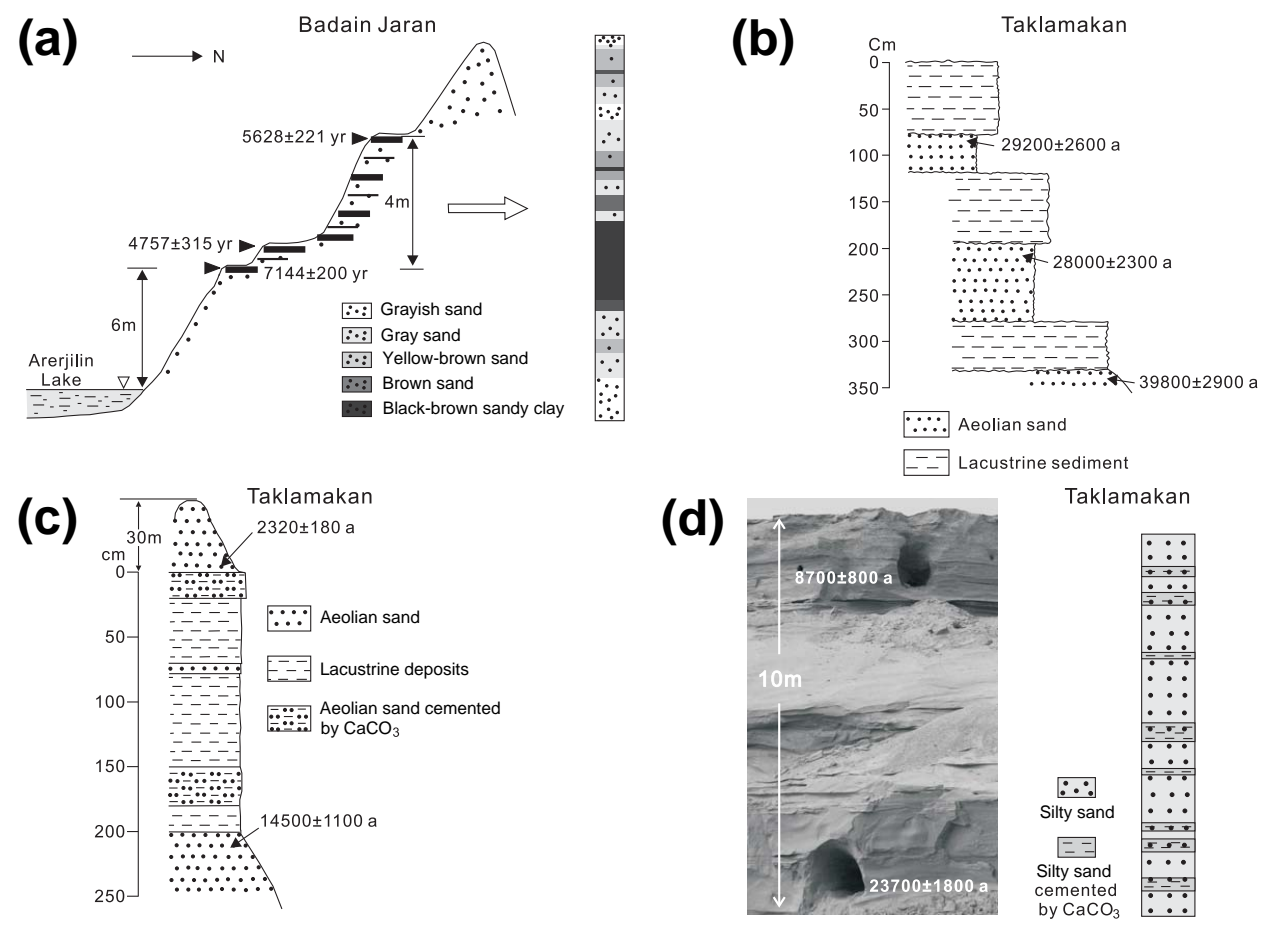

Figure 3. Sketch maps of the sedimentary profiles studied in this study. (a) Lacustrine sediments interbedded by aeolian sand layers with ${ }^{14} \mathrm{C}$ ages at the Arerjilin-I section in the Badain Jaran Desert, (b) interbedding of aeolian and lacustrine deposits and their OSL ages at the Tazhong-XIII section in the Taklamakan Desert, (c) lacustrine deposits buried under a $30 \mathrm{~m}$ high dune at the Yaogan-VIII section in southern Taklamakan, and (d) sandy loess deposits with OSL dating results at the Tumiya-II section on the southern margin of the Taklamakan Desert.

In the Tumiya-II section that deposited on the palaeoterrace of the Tumiya River near the south margin of the Taklamakan Desert, the OSL chronology is dated to between $23700 \pm 1800$ a and $8700 \pm 800$ a (Table S4). The accumulation of sandy loess at this section indicates that southern margin of the Taklamakan Desert at the time between $23700 \pm 1800$ and $8700 \pm 800$ a was wet.

The above chronological data show that the OSL data hold great uncertainty. It may be necessary to discuss the uncertainty in different locations in this study. As previously reported, textures such as grain size and shape are important parameters influencing the OSL dating of sediment (Aitken, 1985; Fain et al., 1999; Brennan, 2003; Guerin et al., 2012; Duval et al., 2015), since they have a direct impact on several correction factors that are used for evaluating the dose rate. The aeolian sand layers for OSL dating in the Tazhong-XIII section have a mean particle sizes of 3.3-3.5 phi (sieving result), which is much coarser than the interbedded lacustrine deposits (mean particle size 5.8-6.7 phi). The aeolian sand layers in the Yaogan-VIII section have a mean grain size of $3.8 \mathrm{phi}$, also coarser than the intercalated lacustrine deposits (mean particle size 4.6-6.2 phi). Aeolian silt or sandy loess deposits in the Tumiya-II section have a mean grain size of 3.6-4.0 phi. These data show a large variability in terms of size of grains between the samples for OSL dat- ing in the Taklamakan Desert. Because there is a difference between the sieve aperture size, or sieve opening, and the diameter of a particle, consequently, the main dimension controlling the sorting of the grains for non-spherical particles is the so-called intermediate diameter. For example, for standard meshes of 50,100, 200, and $300 \mathrm{~mm}$, the grains passing through may have an intermediate dimension in the range of 50-71, 100-141, 200-283, and 300-424 mm, respectively (Duval et al., 2015). Further, the grain size distribution of the raw sediment may have also an impact on the dating results, like in the case of a bimodal distribution (Duval et al., 2015). So the principal sources of uncertainty in the OSL dating data of this study may potentially be derived from the grain size of aeolian sediments. On the other hand, the difference in ${ }^{14} \mathrm{C}$ ages between the uppermost and lowermost organic carbon layers of a sediment profile usually underestimates the time of sediment deposition, and the difference in OSL ages taken from sediment units overlying and underlying a buried soil most likely overestimates it (Miao et al., 2016). For example, the comparison of OSL and ${ }^{14} \mathrm{C}$ ages suggests that the radiocarbon dating technique may significantly underestimate the age of sediments for samples older than $30 \mathrm{cal} \mathrm{ka} \mathrm{BP}$ (corresponding to $\sim 25{ }^{14} \mathrm{C} \mathrm{ka} \mathrm{BP}$ ) (Long et al., 2015). This factor could also lead to a degree of uncertainty in the chronological data of this study. 

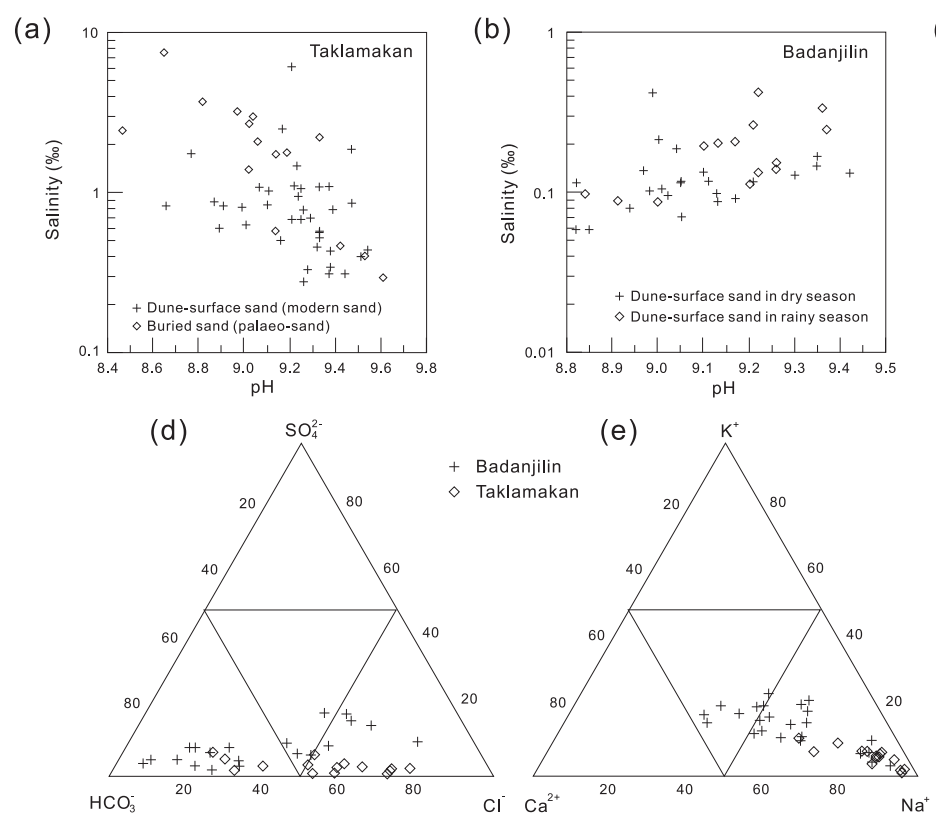
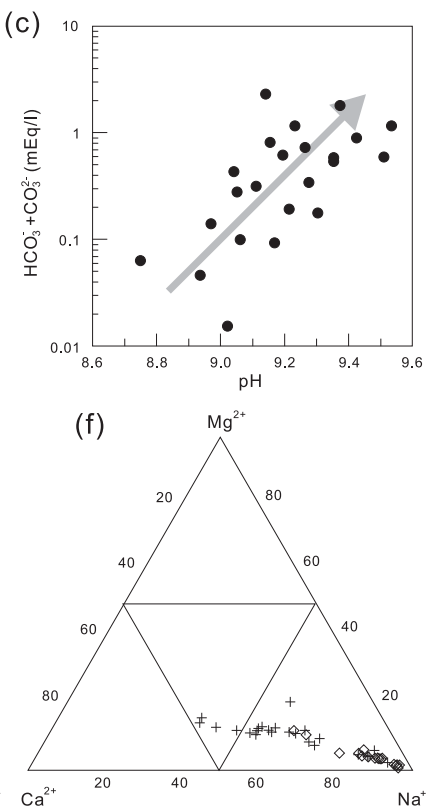

(g)

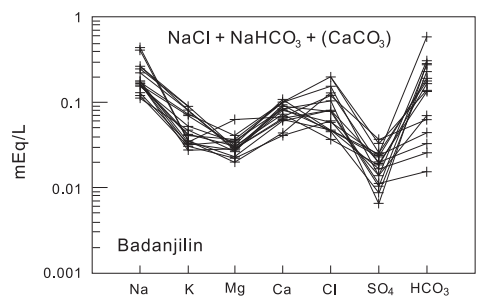

(h)

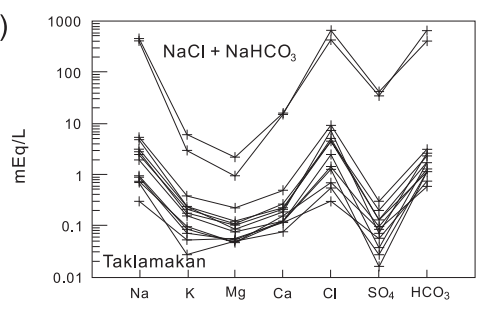

Figure 4. Salinities vs. pH of sediment solutions: (a) dune-surface sediments (modern sediment) and buried-dune sediments (palaeosediment) in the Taklamakan Desert, (b) dune-surface sand samples collected in different climatic seasons (dry and wet) in the Badain Jaran Desert. (c) Carbon-bearing ions vs. $\mathrm{pH}$; triangular plots of major anions (d) and cations (e, f) of the soluble salts in mEq $\mathrm{L}^{-1}$ unit. Distribution patterns of the major ions of the soluble salts in the aeolian sediments from (g) the Badain Jaran Desert and (h) the Taklamakan Desert.

\section{Discussion}

\subsection{Primary or secondary salt in origin?}

First, it is necessary to understand whether the nature of soluble salt in aeolian sediment is primary or secondary in origin. As defined by Warren (2006), an original salt deposit (evaporite) is hydrologically driven by solar evaporation and is sourced from saturated brine at the ground surface or near-surface. In order to emphasize the highly reactive nature of soluble salts in the sedimentary realm, such salts as are precipitated from surface brine and which retain crystallographic evidence of the depositional process are regarded as primary salts. According to this definition and the related two limiting factors, almost every subsurface salt texture is secondary, because it is diagenetically altered, frequently with fabrics indicating pervasive early recrystallization. Secondary salts can be formed in surface/subsurface settings equivalent to the eogenetic, mesogenetic, and telogenetic realms (Choquette and Pray, 1970). Using this defini- tion of a primary versus secondary salt, we can say that, outside of a few Neogene examples (Riding et al., 1998; ValeroGarces et al., 1999, 2001; Pedley et al., 2003), there are few salt deposits with textures that are wholly and completely "primary". Without exception, soluble salts in aeolian sediments should be secondary salts originated in the eogenetic realm.

According to the salt categories defined by Warren (2006), salt minerals can be simply subdivided into evaporitic alkaline earth carbonates and evaporite salts. Regarding the depositional process, evaporitic alkaline earth carbonates are the first-precipitated salt minerals that are sourced from concentrating hypersaline water. Compared with the evaporite salts, they tend to be formed during the early stages of surface brine concentration-crystallization, while the evaporite salts are formed during the more saline stages of the concentrationcrystallization process (Smoot and Lowenstein, 1991). As analysed above, $\mathrm{NaHCO}_{3}+\mathrm{CaCO}_{3}$ are components in dune sediments from both the Taklamakan and the Badain Jaran 

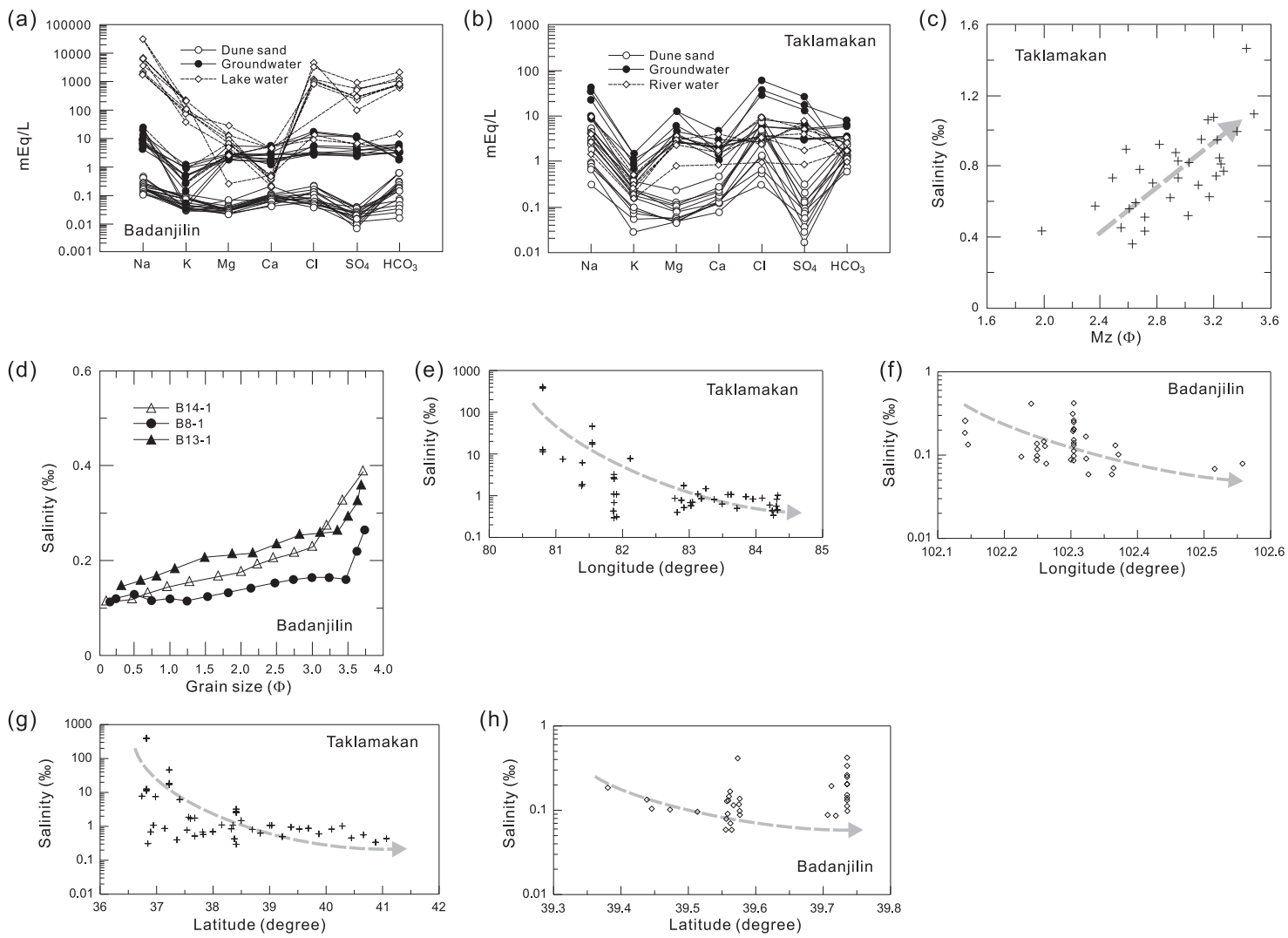

Figure 5. Distribution patterns of the major ions of aeolian salts, groundwaters and lake waters in (a) the Badain Jaran Desert and (b) the Taklamakan Desert. The data of local lake water and groundwater bodies in the Badain Jaran are cited from Yang and Williams (2003), and the river water and groundwater bodies in the Taklamakan from Zhu and Yang (2007). The relationship between salinities and grain size compositions of the aoelian sediments: (c) salinity vs. median particle diameter (Mz, in phi unit) of dune-surface sediment from the Taklamakan Desert, and (d) salinity vs. grain size compositions of randomly selected dune sediments from the Badain Jaran Desert. Spatial distributions of the salinities of the aeolian sediments along the longitudinal and latitudinal degrees in the Taklamakan Desert (e, $\mathbf{g}$ ) and in the Badain Jaran Desert (f, h), respectively.

deserts. This shows that the evaporitic alkaline earth carbonates are major components of these aeolian salts.

Although the texture of most of the subsurface salts is secondary, the earliest secondary salts are often syndepositional precipitates (Warren, 2006), with the formation of cements and replacement even as the primary matrix accumulates around them. For example, nodular anhydrite and aragonite were recognized in Permian mudflats by Kerr and Thomson (1963) - they were interpreted as a subaqueous saline pan indicator. Works by Gerdes et al. $(1994,2000)$ have shown that carbonate grains, such as ooids and peloids, typically thought of as indicators of marine conditions and mechanical agitation, can precipitate in situ in $\mathrm{CaCO}_{3}$-saturated evaporitic settings. For aeolian sediments in arid environment, we imagine that much of the surface salts are deposited in multiple episodes of early diagenetic (syndepositional) cementation. This syndepositional salt may be formed in multiple dissolution-precipitation events in the sand particle surface and be precipitated between successive depositional episodes of salt crust formation.

Besides alkaline earth carbonates $\left(\mathrm{NaHCO}_{3}+\mathrm{CaCO}_{3}\right)$, $\mathrm{NaCl}$ is another major component of aeolian salts in the deserts studied. This salt, dominantly halite, is an evaporite salt according to the classification of Warren (2006), that has been precipitated from concentrated brine after the brine has crystallized the alkaline earth carbonates. Both the evaporitic alkaline earth carbonates and evaporite salts coexist in the aeolian sediments of the deserts, indicating that aeolian salts are complex salt mixtures formed by multiple evaporation and precipitation processes in the eogenetic realm.

\subsection{Possible mechanism of aeolian salt formation}

All evaporite salts are ionic salts. The definition of a salt deposit (evaporite) proposed by Warren (2006), as mentioned above, has no assumption as to the origin of the parent brine. It may be marine, nonmarine or a hybrid (Smoot and Lowenstein, 1991). By definition, there is a need for aridity and 

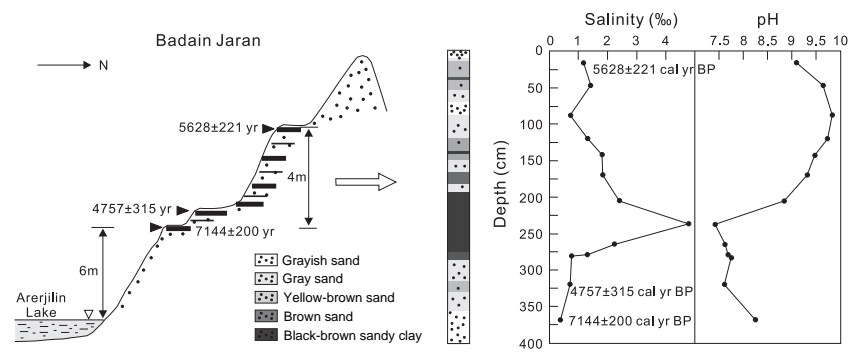

Figure 6. Sequential variations in soluble salt contents (salinity and $\mathrm{pH}$ ) of the Arerjilin-I section in the Badain Jaran Desert.
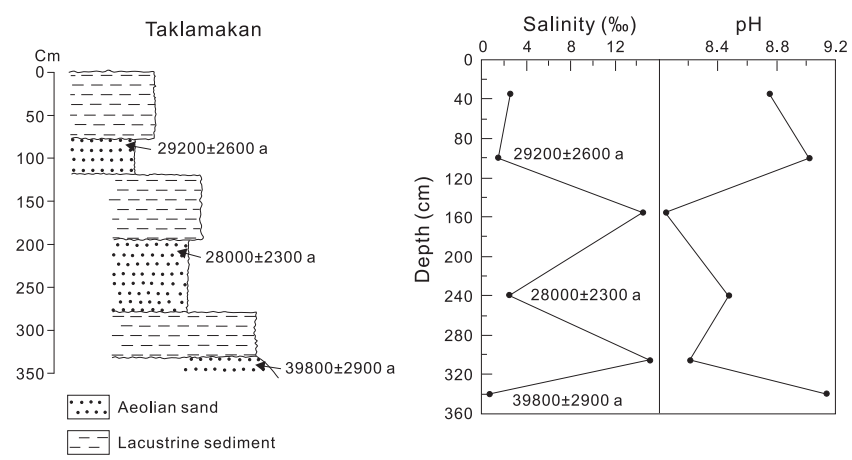

Figure 7. Sequential variations in soluble salt contents (salinity and $\mathrm{pH})$ of the Tazhong-XIII section in the Taklamakan Desert.

for water loss to exceed inflow (Borchert and Muir, 1964). This means that deposition and diagenesis in evaporites is more dependent on climate than in either siliciclastic or carbonate sediments. Therefore, modern continental evaporites typically accumulate in semi-arid to hyperarid deserts. Suites of precipitated salts follow the geochemical make-up of the parent brine (Braitsch, 1971). This means that the mineralogy and order of precipitates in any brine pool are controlled by the ionic make-up of the parent brine. This provides a clue to the possible source and mechanism of salt formation under a particular environment.

Generally speaking, eight mechanisms or processes precipitate most salt minerals and crusts worldwide: (1) in situ pedogenic weathering and eluviation processes of existing salty or volcanogenic (ash) parent materials; (2) eolian or fluvial input of salt or salt-rich sediment; (3) upward movement of salt via capillary flow from a shallow salty groundwater, (4) an oceanic aerosol source, creating in salt-enriched rainfall that evaporatively concentrates within the regolith, (5) intrusion and flooding by seawater, (6) decomposition of vegetation, (7) in situ oxidation of sulfide minerals, (8) anthropogenic pollutants (Petrov, 1976; Smoot and Lowenstein, 1991; Warren, 2006; Singer, 2007). The first two sources are direct evaporite associations, while the third is typically associated with salt lakes, sabkhas, and playas in semi-arid or desert settings within $500-1000 \mathrm{~km}$ of the coast. Many salt soil horizons are combinations of both pedogenically precip-
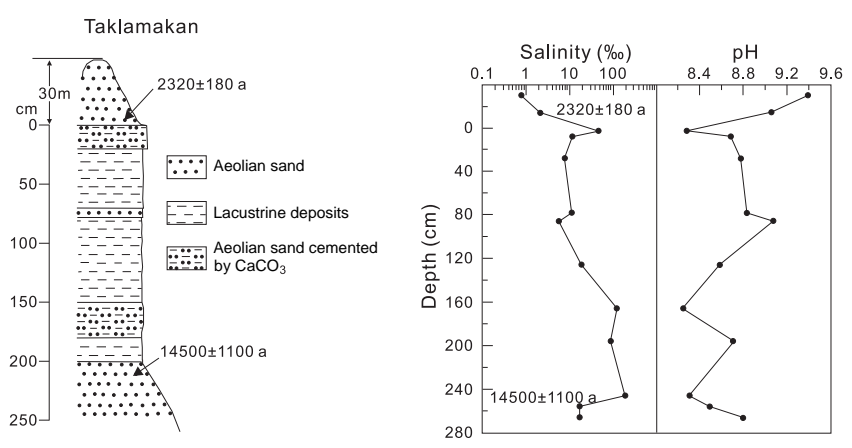

Figure 8. Sequential variations in soluble salt contents (salinity and $\mathrm{pH})$ of the Yaogan-VIII section in the Taklamakan Desert.
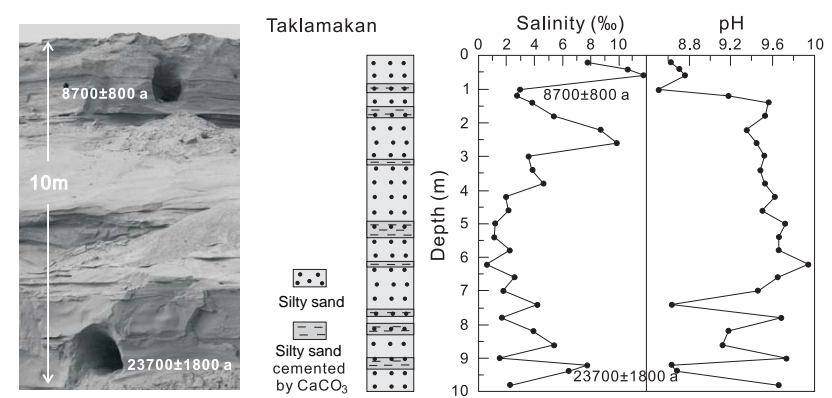

Figure 9. Sequential variations in soluble salt contents (salinity and $\mathrm{pH})$ of the Tumiya-II section in the Taklamakan Desert.

itated and detrital wind-reworked salt (Warren, 2006; Singer, 2007). The eight possible mechanisms can give us clues as to the possible mechanism of aeolian salt formation in Chinese deserts.

Regarding the weathering mechanism in view (1), our previous study has shown that the degree of weathering of aeolian sand in the Taklamakan Desert is very low (CIA $\approx 50$ ) (Zhu and Yang, 2009), similar to that of the un-weathered Upper Continental Crust. This suggests that salt contributions directly from bedrock weathering are of minor significance. For the eluviation processes of mechanism (1), studies have demonstrated that in a region with a mean annual precipitation of less than $500 \mathrm{~mm}$, the export of erosible elements by eluviation processes in the soil will be less significant than their preservation by evaporation-crystallization processes (Birkeland, 1999; Kraimer et al., 2005). Since the mean annual precipitation in the desert regions of northern China is lower than $400 \mathrm{~mm}$ (Fig. 1a), the degree of eluviation exerted on soluble salts in the two sandy seas is lower than that of preservation. The salt concentrations of samples buried in dune subsurface layers in this study are equal to or only slightly higher than those of the surface samples (Fig. 4a), indicating that only a little downward movement of these salts is taking place. Case studies on salt movement in desert soil have also shown that only $1.64 \%$ of the rainfallleached salt can reach $1.0 \mathrm{~m}$ depths, and only $0.02 \%$ of the 
rainfall-leached salt can penetrate $2.0 \mathrm{~m}$ below the ground surface (Marion et al., 2008). This means that the salt contributions from eluviation processes of parent salts are also minor.

Regarding mechanism (3), dunes in both the Taklamakan and Badain Jaran Deserts are generally higher than 20-50 m (Zhu et al., 1980) - in particular being higher than $200 \mathrm{~m}$ in the Badain Jaran Desert - so it is impossible for groundwater to contribute salt to aeolian sediments by being drawn upward to the dune surface via capillarity.

Regarding mechanisms (4) and (5), both the two sandy deserts studied are geographically far away from any ocean and have been under the control of terrestrial processes since at least the Cenozoic (Zhu et al., 1980). Salt contributions from present or ancient seawater and aerosol can, therefore, be neglected. However, contributions from oceanic-sourced rainfall precipitation (atmospheric wet deposition) will be discussed below.

Regarding mechanism (6), although the decomposition of vegetation may contribute to the salts of some desert areas (Petrov, 1976), but plants in/around the sampling sites of the deserts in this study are scarce, so any influence of vegetation is minimal.

Regarding mechanism (7), Petrov (1976) suggested that the salt chemistry in the world deserts can be classified into four types: chloride, sulfate, carbonate, and mixed. Many desert soils in arid to semi-arid environment are sulfate-rich in areas surrounding the perennial saline lakes, the brine pan depressions, and their dune margins (Petrov, 1976; Smoot and Lowenstein, 1991; Warren, 2006). For example, gypsum crusts have been reported from all the continents, including the Antarctic (El-Sayed, 1993). Studies have shown that chloride-sulfate salts but not bicarbonate salts dominate in the Kalahari Desert (Wang et al., 2009). This is also the case for the wind-distributed aeolian loess deposits in the Loess Plateau of northern China (Zhu et al., 2012), which are mainly composed of $\mathrm{Na}_{2} \mathrm{SO}_{4}+\mathrm{NaHCO}_{3}$ for loess and of $\mathrm{Na}_{2} \mathrm{SO}_{4}+\mathrm{NaCl}+\mathrm{NaHCO}_{3}$ for palaeosol (Sun et al., 2006), while the analysis of this study shows that aeolian salts in the Taklamakan and Badain Jaran deserts are a mixture of sodium bicarbonate and chloride. This is different from both the Chinese loess deposits and the global tropical/subtropical deserts. Although sodium sulfate $\left(\mathrm{Na}_{2} \mathrm{SO}_{4}\right)$ is an important salt in loess-palaeosol sequences, it is less common in the dune sediments from the sandy deserts in this study. So the mechanism of in situ oxidation of sulfide minerals can be excluded for the aeolian salts in this study.

Regarding mechanism (8), anthropogenic pollutants, generated by human activities, are usually inorganic ions such as $\mathrm{NH}_{4}^{+}, \mathrm{NO}_{3}^{-}, \mathrm{H}_{2} \mathrm{PO}_{4}^{-}$, and $\mathrm{SO}_{4}^{2-}$, and some organic anions. The contents of all samples studied, however, have roughly equivalent numbers of cations and anions with low amount (or none) of the above-mentioned ions (Table S2), suggesting that human impact on salt concentrations across the two sandy deserts is negligible.
On the basis of all the above results, only mechanism (2) is unexplained. Mechanism (2) involves the hydrological and atmospheric processes of salt origin and transportation. We discuss this below.

\subsection{Atmospheric origin?}

There are wide similarities but partial differences existing in the salt chemistry and ion distribution patterns of aeolian salts between the Taklamakan and Badain Jaran deserts (Fig. 4g-h). Further, they are weakly correlated with the chemical compositions of the nearby ground waters under their local hydrological setting (Zhu and Yang, 2010) (Fig. 5a-b), but are strongly associated with the regional climatic and wind regime (Zhu et al., 2012) (Fig. 5c-h). All this evidence indicates that the natural system of aeolian salts is hydrologically open and the chemistry of the parent brines and the associated salt deposits may be significantly different from that predicted for hydrologically closed systems. This means that the sources of aeolian salts in the deserts are strongly controlled by the earth surface processes at a regional or large scale, but not at a local scale. From this point of view, only an atmospheric origin (and not a hydrological origin) can be responsible for this pattern.

It has been recognized that atmospheric chemical species are a significant source contributing acidic and eutrophic elements to both terrestrial and ocean ecosystems (e.g. Sehmel, 1980; Wesely and Hicks, 2000; Inomata et al., 2009). For example, soil salts in many desert areas have been found to originate from atmospheric sources (Amit and Yaalon, 1996; Bohlke et al., 1997; Oyarzun and Oyarzun, 2007). Generally, there are two forms of atmospheric deposition: wet and dry deposition. Wet deposits contain salts derived from rainwater and snow. Studies have shown that chloride and carbonate are major species in rainfall in central Asia and north China (Fujita et al., 2000; Li et al., 2007; Zhao et al., 2008). This indicates that the chemical compositions of wet depositions and aeolian salts are similar.

As well as rainfall, aerosol and dust, known as atmospheric dry deposition, is another global phenomenon of salt transportation (Goudie and Middleton, 2006). At present there are few data available for understanding the salt compositions of dust in the study areas. However, wider studies have shown that salt transportation and redeposition via dust are one of the important patterns for biogeochemical cycles in arid areas (Logan, 1974; Yaalon and Ginzboung, 1966; Reheis and Kihl, 1995; Al-Momani et al., 1995; Kiefert, 1997; Blank et al., 1999; Kulshrestha et al., 2003; Zheng et al., 2005; Abuduwaili et al., 2009). The same should apply for the hinterlands of northwestern China. 


\subsection{Climatic implications}

The coexistence of palaeo-lacustrine sediments (playa) and aeolian sediments is commonly seen in desert regions globally. This is clear evidence of past environmental changes in desert conditions (Smith, 1971; Yechieli and Wood, 2002; Alonso-Zarza, 2003; Yang et al., 2006; Tripaldi et al., 2011; Dong et al., 2012), Therefore, the large number of playa deposits in the inter-dune depressions of these deserts offers an exceptional opportunity to study regional palaeohydrological and palaeoclimatic change. Over the past decade, there have been significant advances in our understanding of the late Quaternary history of the desert regions of northwestern China. OSL and ${ }^{14} \mathrm{C}$ chronologies of aeolian sediments from various locations in these deserts provide important archives to help understand the timing of lacustrine/fluvial and aeolian processes related to environmental and climate changes. However, despite this increased interest, palaeolimnological and palaeo-aeolian research is limited by a paucity of potential geoproxy and study sites with relatively long, uninterrupted stratigraphic sequences. Sequential variations of inorganic salts have been tentatively applied to reconstruct the palaeoenvironmental history in desert areas. For instance, taking the soluble salt variations in thick Cenozoic deposits as one of the indicators of palaeoenvironmental change, Sun et al. (2008) reconstructed the aridity history of the Tarim Basin and argued that a hyperarid climate had prevailed within the basin since $5.3 \mathrm{Ma}$ ago.

The variations in soluble salt contents for the four sections collected from the Taklamakan and Badain Jaran deserts have been examined in this study, as shown in Figs. 6-9. The OSL and ${ }^{14} \mathrm{C}$ age constraints of these sequences are also shown. The data indicate that all of these playa deposits had experienced fluctuations in high moisture conditions during the period from the late Pleistocene to mid-Holocene.

For the Arerjilin-1 section, there is an increase-decline pattern in salinity variation and a decline-increase-decline pattern in $\mathrm{pH}$ variation during the early-middle Holocene (Fig. 6). For the Tazhong-XIII section, there is a clear serrated shape (Fig. 7) in the pattern of salinity variation. This indicates that there have been at least three periods of humid environmental fluctuations during the past 40 to $28 \mathrm{ka} \mathrm{BP}$. In the Yaogan-VIII section, the sequence salinities are relatively high (Fig. 8), suggesting that a saline lacustrine environment has occurred in this area and the local hydrological settings have retained the saline conditions for a long time from the end of the last glacial to late Holocene. In the Tumiya-II section, variations of the sequence salinities were unstable during the LGM (24 ka BP). There are two stages of salinity increase - during the end of the LGM (about 10-11 ka) and in the early Holocene (after $8.7 \mathrm{ka} \mathrm{BP}$ ) (Fig. 9). Considering the four sections as a whole, there are evident differences between the aeolian sediments and fluvial sediments in regard to salt content. In general, salinities in aeolian sediments are clearly lower than those of lacustrine sediments.
This suggests that a great salt depositional discrepancy exists between the aeolian and the lacustrine sedimentary systems, which could be due to the different mechanisms of salt formation and origin in wind and water regimes. The results suggest that inorganic salt is a latent proxy indicator for a single depositional-environment sequence in revealing local hydrological variations and climate changes in desert areas during the late Quaternary.

However, the interpretation based on salt archives should be done cautiously for sedimentary sequences with dual/multiple depositional end-members. Researchers have reported that in sediment strata formed by an identical geological process like lacustrine or aeolian dynamics, the increase of sequence salinity commonly reflects a stepped-up environmental aridity (Sinha and Raymahashay, 2004; Warren, 2006; Liu et al., 2008). Because whatever the underlying the aeolian and lacustrine depositional settings, the increase in salt content is a reflection of enhanced evaporation potential. However, in a sediment profile controlled by multiple geological processes like combined aeolian and lacustrine dynamics, the increase in salt content could be not a reflection of the enhanced aridity, just as the case in this study. The lacustrine sediments are generally higher in salinity than are the aeolian sediments. In this study, the salinity increases in sections of the Arerjilin-I, Tazhong-XIII, and Yaogan-VIII are in general a representation of the enhanced wetter conditions (Figs. 6-8), because the higher salinities are always located in the lacustrine/fluvial layers. In general, lacustrine/fluvial strata in aeolian sequences always reflect more enhanced humid periods than that of the aeolian period (Yang et al., 2006). However, this is not the case for the Tumiya-II section, where the salt increases should be attributed to enhanced aridity (Fig. 9), because the sedimentary structure of this section is uniformly dominated by aeolian processes. Thus it can be confirmed that once the coexistence of aeolian and fluvial/lacustrine sediments is identified in a sedimentary structure in desert regions, one should be cautious in reconstructing the regional environmental changes via the single use of salt archives. A combined use of salt archives and sedimentary proxies is recommended in this situation.

Further, land surface processes such as chemical, physical, and mechanical processes can weld younger to older sediment profiles and affect the accumulation, dissolution, and reprecipitation of mineral materials in sediments, as illustrated by Olson and Nettleton (1998). Sediment properties most affected include texture and the content and distribution of soluble salts. Processes such as erosion and deposition can truncate profiles or bury them either rapidly or extremely slowly. The effects of these and other processes on sediment properties must be examined with care in palaeosols that have been buried even for a short interval. The above-mentioned fluvial/lacustrine-aeolian profiles in the Taklamakan and Badain Jaran deserts should be considered carefully in future studies and possibly avoided as 
single indicators in palaeoenvironmental reconstructions in the desert environment.

\section{Conclusion}

Formations of inorganic salt in aeolian sediments in the desert environment are significant for understanding the interrelationships between aoelian dynamics and regional geological and climate regimes. Geological information related to inorganic salt composition and distribution and their environmental significance in aeolian sediments in mid-latitude deserts is still scarce. The geochemistry of soluble salts in modern and ancient dune sediments from the sandy deserts in northwestern China was surveyed in this work. Variations of the salt composition in and around these sandy deserts are closely related to regional climatic parameters, such as precipitation, temperature, and wind. It is suggested that the aeolian salts derive from the atmospheric depositions that are strongly associated with the local-scale and regional-scale dry and wet depositions, such as rainfall and dustfall precipitation. A single salt archive in sedimentary deposits interlayered by aeolian and lacustrine facies should be used with care as a geoproxy to reconstruct palaeoenvironmental histories in arid conditions.

\section{The Supplement related to this article is available online at doi:10.5194/se-7-191-2016-supplement.}

Acknowledgements. The study was funded by the Kezhen Young Talent Project of the IGSNRR-CAS (grant no. 2013RC101) and the National Natural Science Foundation of China (grant nos. 41371060, 41225001, 41271049). Sincere thanks are extended to Xiaoping Yang for his generous help in the field work. The author is very grateful to Artemi Cerda, the topical editor of the Solid Earth, and three anonymous reviewers for their constructive comments, which improved the quality of the paper.

Edited by: A. Cerdà

\section{References}

Abuduwaili, J., Gabchenko, M. V., and Xu, J.: Eolian transport of salts - a case study in the area of Lake Abinur (Xinjiang, Northwest China), J. Arid Environ., 72, 1843-1852, 2009.

Agata, N., Cerda, A., Carmelo, D., Giuseppe, L. P., Antonino, S., and Luciano, G.: Effectiveness of carbon isotopic signature for estimating soil erosion and deposition rates in Sicilian vineyards, Soil Till. Res., 152, 1-7, 2015.

Ahuja, L. R.: Modeling soluble chemical transfer to runoff with rainfall impact as a diffusion process, Soil Sci. Soc. Am. J., 54, 312-321, 1990
Aitken, M. J.: Thermoluminescence Dating, Academic Press, London, 1985.

Al-Momani, I. F., Tuncel, S., Eler, U., Ortel, E., Sirin, G., and Tuncel, G.: Major ion composition of wet and dry deposition in the eastern Mediterranean basin, Sci. Total Environ., 164, 75-85, 1995.

Alonso-Zarza, A. M.: Palaeoenvironmental significance of palustrine carbonates and calcretes in the geological record, Earth-Sci. Rev., 60, 261-298, 2003.

Amit, R. and Yaalon, D. H.: The micromorphology of gypsum and halite in reg soils - the Negev Desert, Israel, Earth Surf. Proc. Land., 21, 1127-1143, 1996.

Birkeland, P. W.: Soils and Geomorphology, Oxford University Press, New York, 1999

Blank, R. R., Young, J. A., and Allen, F. L.: Aeolian dust in a saline playa environment, Nevada, USA, J. Arid Environ., 41, 365-381, 1999.

Brennan, B. J.: Beta doses to spherical grains, Radiat. Meas., 37, 299-303, 2003.

Bodi, M. B., Doerr, S. H., Cerda, A., and Mataix-Solera, J.: Hydrological effects of a layer of vegetation ash on underlying wettable and water repellent soil, Geoderma, 191, 14-23, 2012.

Bodi, M. B., Martin, D. A., Balfour, V. N., Santin, C., Doerr, S. H., Pereira. P., Cerda, A., and Mataix-Solera, J.: Wildland fire ash: Production, composition and eco-hydro-geomorphic effects, Earth-Sci. Rev., 130, 103-127, 2014.

Bohlke, J. K., Ericksen, G. E., and Revesz, K.: Stable isotope evidence for an atmospheric origin of desert nitrate deposits in northern Chile and southern California, USA, Chem. Geol., 136, 135-152, 1997.

Borchert, H. and Muir, R. O.: Salt Deposits: The Origin, Metamorphism and Deformation of Evaporites, Van Nostrand Company, London, 1964.

Braitsch, O.: Salt Deposits: Their Origin and Composition, Springer-Verlag, Berlin, 1971.

Cerda, A., Brazier, R., Nearing, M., and de Vente, J.: Scales and erosion, Catena, 102, 1-2, 2013.

Choquette, P. W. and Pray, L. C.: Geological nomenclature and classification of porosity in sedimentary carbonates, AAPG Bull., 54 207-250, 1970.

Dan, J. and Yaalon, D. H.: Automorphic saline soils in Israel, Catena, 1, 103-115, 1982.

Dean, W. E. and Schwalb, A.: Holocene environmental and climatic change in the Northern Great Plains as recorded in the geochemistry of sediments in Pickerel Lake, South Dakota, Quaternary Int., 67, 5-20, 2000.

Dragovich, D. and Dominis, M.: Dryland salinity and rainfall patterns: a preliminary investigation in central 5 west New South Wales (Australia), Land Degrad. Dev., 19, 564-573, 2008.

Dong, Z., Lv, P., Qian, G., Xia, X., Zhao, Y., and Mu, G.: Research progress in China's Lop Nur, Earth-Sci. Rev., 111, 142$153,2012$.

Duval, M., Campana, I., Guilarte, V., Miguens, L., Iglesias, J., and Sierra, S.G.: Assessing the uncertainty on particle size and shape: Implications for ESR and OSL dating of quartz and feldspar grains, Radiat. Meas., 81, 116-122, 2015.

El-Sayed, M. I.: Gypcrete of Kuwait: field investigation, petrography and genesis, J. Arid Environ., 25, 199-203, 1993. 
Fain, J., Soumana, S., Montret, M., Miallier, D., Pilleyre, T., and Sanzelle, S.: Luminescence and ESR dating beta-dose attenuation for various grain shapes calculated by a Monte-Carlo method, Quaternary Sci. Rev., 18, 231-234, 1999.

Fujita, S., Takahashi, A., Weng, J., Huang, L., Kim, H., Li, C., Huang, F. T. C, and Jeng, F.: Precipitation chemistry in East Asia, Atmos. Environ., 34, 525-537, 2000.

Gerdes, G., Dunajtschik-Piewak, K., Riege, H., Taher, A. G., Krumbein, W. E., and Reineck, H. E.: Structural diversity of biogenic carbonate particles in microbial mats, Sedimentology, 41, 12731294, 1994.

Gerdes, G., Krumbein, W. E., and Noke, N.: Evaporite microbial sediment. in: Microbial Sediments, edited by: Riding, R. E. and Awramik, S. M., Springer-Verlag, Berlin, Heidelberg, 196-208, 2000.

Goudie, A. S. and Middleton, N. J.: Desert Dust in the Global System, Springer, Berlin, 2006.

Guerin, G., Mercier, N., Nathan, R., Adamiec, G., and Lefrais, Y.: On the use of the infinite matrix assumption and associated concepts: a critical review, Radiat. Meas., 47, 778-785, 2012.

Handford, C. R.: Marginal marine halite: sabkhas and salinas, in: Evaporites, Petroleum and Mineral Resources, edited by: Melvin, J. L., Elsevier, Amsterdam, 1-66, 1991.

Hay, W. W., Migdisov, A., Balukhovsky, A. N., Wold, C. N., Flogel, S., and Soding, E.: Evaporites and the salinity of the ocean during the phanerozoic: implications for climate, ocean circulation and life, Palaeogeogr. Palaeocl., 240, 3-46, 2006.

Inomata, Y., Igarashi, Y., Chiba, M., Shinoda, Y., and Takahashi, H.: Dry and wet deposition of water-insoluble and water-soluble chemical species during spring 2007 in Tsukuba, Japan, Atmos. Environ., 43, 4503-4512, 2009.

Kerr, S. D. J. and Thomson, A.: Origin of nodular and bedded anhydrite in Permian shelf sediments, Texas and New Mexico, AAPG Bull., 47, 1726-1732, 1963.

Kiefert, L.: Characteristics of wind transported dust in eastern Australia, Dissertation, Griffith University, Brisbane, Australia, 1997.

Kraimer, R. A., Monger, H. C., and Steiner, R. L.: Mineralogical distinctions of carbonates in desert soils, Soil Sci. Soc. Am. J., 69, 1773-1781, 2005.

Kulshrestha, M. J., Kulshrestha, U. C., Parashar, D. C., and Vairamani, M.: Estimation of SO4 contribution by dry deposition of SO2 onto the dust particles in India, Atmos. Environ., 37, 30573063, 2003.

Lasanta, T. and Cerda, A.: Long-term erosional responses after fire in the Central Spanish Pyrenees: 2. Solute release, Catena, 60, 81-100, 2005.

Last, W. M.: Paleochemistry and paleohydrology of Ceylon Lake, a salt-dominated playa basin in the Northern great plains, Canada, J. Paleolimnol., 4, 219-238, 1990.

Last, W. M. and Vance, R. E.: The Holocene history of Oro Lake, one of the western Canada's longest continuous lacustrine records, Sediment. Geol., 148, 161-184, 2002.

Lavee, H., Imeson, A. C., Pariente, S., and Benyamini, Y.: The response of soils to simulated rainfall along a climatological gradient in an arid and semi-arid region, Catena, 19, 19-37, 1991.

Li, C., Kang, S., Zhang, Q., and Kaspari, S.: Major ionic composition of precipitation in the Nam Co region, Central Tibetan Plateau, Atmos. Res., 85, 351-360, 2007.
Liu, X., Dong, H., Rech, J. A., Matsumoto, R., Yang, B., and Wang, Y.: Evolution of Chaka Salt Lake in NW China in response to climatic change during the latest pleistocene-holocene, Quaternary Sci. Rev., 27, 867-879, 2008.

Logan, J.: African dusts as a source of solutes in Gran Ganaria ground waters, Geological Society of America, 6, 849, Abstracts with Programs, 1974.

Long, H., Shen, J., Wang, Y., Gao, L., and Frechen, M.: Highresolution OSL dating of a late Quaternary sequence from Xingkai Lake (NE Asia): chronological challenge of the "MIS3a Mega-paleolake" hypothesis in China, Earth Planet. Sc. Lett., 428, 281-292, 2015.

Marion, G. M., Verberg, P. S. J, McDonald, E. V., and Arnone, J. A.: Modeling salt movement through a Mojave Desert soil, J. Arid Environ., 72, 1012-1033, 2008.

Miao, X., Wang, H., Hanson, P. R., Mason, J. A., and Liu, X.: A new method to constrain soil development time using both OSL and radiocarbon dating, Geoderma, 261, 93-100, 2016.

Olson, C. G. and Nettleton, W. D.: Paleosols and the eects of alteration, Quaternary Int., 51/52, 185-194, 1998.

Oyarzun, J. and Oyarzun, R.: Massive volcanism in the AltiplanoPuna Volcanic Plateau and formation of the huge Atacama Desert nitrate deposits: a case for thermal and electric fixation of atmospheric nitrogan, Int. Geol. Rev., 49, 962-968, 2007.

Pariente, S.: Soluble salts dynamics in the soil under dierent climatic conditions, Catena, 43, 307-321, 2001.

Pedley, M., Martin, J. A. G., Delgado, S. O., and Del Cura, D.: Sedimentology of Quaternary perched springline and paludal tufas: criteria for recognition, with examples from Guadalajara Province, Spain, Sedimentology, 50, 23-44, 2003.

Petrov, M. P.: Deserts of the World, John Wiley \& Sons, New York, 1976.

Reheis, M. C. and Kihl, R.: Dust deposition in southern Nevada and California, 1984-1989: relatins to climate, source area and source lithology, J. Geophys. Res., 100, 8893-8918, 1995.

Rengasamy, P., Greene, R. S. B, and Ford, G. W.: The role of clay fraction in the particle arrangement and stability of soil aggregates - a review, Clay Research, 3, 53-67, 1984.

Riding, R., Braga, J. C., Martin, J. M., and Sanchezalmazo, I. M.: Mediterranean Messinian salinity crisis - constraints from a coeval marginal basin, Sorbas, southeastern Spain, Mar. Geol., 146, 1-20, 1998.

Schutt, B.: Holocene paleohydrology of playa-lake systems in central Spain: a reconstruction based on mineral composition of the lacustrine sediments, Quaternary Int., 73/74, 7-27, 2000.

Sehmel, G. A.: Particle and gas dry deposition: a review, Atmos. Environ., 14, 983-1101, 1980.

Singer, A.: Introduction on arid zone soil: salt accumulation and distribution - saline soils. in: Biogeochemistry of Trace Elements in Arid Environments, edited by: Han, F. X., Springer, Dordrecht, 3-44, 2007.

Sinha, R. and Raymahashay, B. C.: Evaporite mineralogy and geochemical evolution of the Sambhar Salt Lake, Rajasthan, India, Sediment. Geol., 166, 59-71, 2004.

Smith, H. T. U: Desert sedimentary environments, Earth-Sci. Rev., 7, A125-A126, 1971.

Smoot, J. P. and Lowenstein, T. K.: Depositional environments of non-marine evaporites. in: Evaporites, Petroleum and Mineral 
Resources, edited by: Melvin, J. L., Elsevier, Amsterdam, 189347, 1991.

Sun, B., Guo, Z., Yin, Q., and Hao, Q.: Soluble salts in a Quaternary loess-soil sequence near Xining and their environmental implications, Quaternary Sci., 26, 649-656, 2006 (in Chinese).

Sun, J., Zhang, L., Deng, C., and Zhu, R.: Evidence for enhanced aridity in the Tarim Basin of China since 5.3 Ma, Quaternary Sci. Rev., 27, 1012-1023, 2008.

Tripaldi, A., Zarate, M. A., Brook, G. A., and Li, G. Q.: Late quaternary paleoenvironments and paleoclimatic conditions in the distal Andean piedmont, southern Mendoza, Argentina, Quaternary Res., 76, 253-263, 2011.

Valero-Garces, B. L., Delgado-Huertas, A., Ratto, N., and Navas, A.: Large ${ }^{13} \mathrm{C}$ enrichment in primary carbonates from Andean Altiplano lakes, northwestern Argentina, Earth Planet. Sc. Lett., 171, 253-266, 1999.

Valero-Garces, B. L., Arenas, C., and Delgado-Huertas, A.: Depositional environments of Quaternary lacustrine travertines and stromatolites from high-altitude Andean lakes, northwestern Argentina, Can. J. Earth Sci., 38, 1263-1283, 2001.

Wang, L., D’Odorico, P., Okin, G., and Macko, S.: Isotope composition and anion chemistry of soil profiles along the Kalahari Transect, J. Arid Environ., 73, 480-486, 2009.

Wang, X., Xia, D., Wang, T., Xue, X., and Li, J.: Dust sources in arid and semiarid China and southern Mongolia: impacts of geomorphological setting and surface materials, Geomorphology, 97, 583-600, 2008.

Warren, J. K.: Evaporites: Sediments, Resources and Hydrocarbons, Springer, Berlin, 2006.

Wasson, R. J., Smith, G. I., and Agrawal, D. P: Late quaternary sediments, minerals, and inferred geochemical history of Didwana lake, Thar Desert, India, Palaeogeogr. Palaeocl., 46, 345-372, 1984.

Wesely, M. L. and Hicks, B. B.: A review of the current status of knowledge on dry deposition, Atmos. Environ., 34, 2261-2282, 2000.

Wetzel, R. G. and Likens, G. E.: Limnological Analyses, 3rd Edn., Springer, New York, 2000.

Yaalon, D. H. and Ginzbourg, D.: Sedimentary characteristics and climatic analysis of easterly dust storms in the Negev (Israel), Sedimentology, 6, 315-322, 1966.
Yang, X. and Williams, M. A. J: The ion chemistry of lakes and late Holocene desiccation in the Badain Jaran Desert, Inner Mongolia, China, Catena, 51, 45-60, 2003.

Yang, X., Preusser, F., and Radtke, U.: Late Quaternary environmental changes in the Taklamakan Desert, western China, inferred from OSL-dated lacustrine and aeolian deposits, Quaternary Sci. Rev., 25, 923-932, 2006.

Yang, X., Ma, N., Dong, J., Zhu, B., Xu, B., Ma, Z., and Liu, J.: Recharge to the inter-dune lakes and Holocene climatic changes in the Badain Jaran Desert, western China, Quaternary Res., 73, 10-19, 2010.

Yechieli, Y. and Wood, W. W.: Hydrogeologic processes in saline systems: playas, sabkhas, and saline lakes, Earth-Sci. Rev., 58, 343-365, 2002.

Zhao, Z., Tian, L., Fischer, E., Li, Z., and Jiao, K.: Study of chemical composition of precipitation at an alpine site and a rural site in the Urumqi River Valley, Eastern Tien Shan, China, Atmos. Environ., 42, 8934-8942, 2008.

Zheng, M., Guo, Z., Fang, M., Rahn, K. A., and Kester, D. R.: Dry and wet deposition of elements in Hong Kong, Mar. Chem., 97, 124-139, 2005.

Zhu, B. and Yang, X.: The ion chemistry of surface and ground waters in the Taklimakan Desert of Tarim Basin, western China, Chinese Sci. Bull., 52, 2123-2129, 2007.

Zhu, B. and Yang, X.: Chemical weathering of detrital sediments in the Taklamakan Desert, Northwestern China, Geogr. Res., 47, 57-70, 2009.

Zhu, B. and Yang, X.: The origin and distribution of soluble salts in the sand seas of northern China, Geomorphology, 123, 232-242, 2010.

Zhu, B., Yang, X., Liu, Z., Rioual, P., Li, C., and Xiong, H.: Geochemical compositions of soluble salts in aeolian sands from the Taklamakan and Badanjilin deserts in northern China, and their influencing factors and environmental implications, Environmental Earth Sciences, 66, 337-353, 2012.

Zhu, Z., Wu, Z., Liu, S., and Di, X.: An Outline of Chinese Sandy Deserts, Science Press, Beijing, 1980 (in Chinese). 